\title{
CONSUMERS' INTENTION TO BUY BRANDED FRESH LEAFY VEGETABLES AMONG RURAL AND URBAN HOUSEHOLDS
}

\author{
Moradeyo Adebanjo OTITOJU * 1,2 (iD), Malgwi Sunday ADAMU ${ }^{2}$, Augustine Sunday ONWUAROH ${ }^{3}$
}

\author{
Address: \\ ${ }^{1}$ Bioresources Development Centre, Ilesha, National Biotechnology Development Agency, Abuja, Nigeria \\ ${ }^{2}$ Department of Agricultural Economics, University of Abuja, Nigeria. \\ ${ }^{3}$ Department of Agricultural Economics and Extension, Federal University of Kashere, Nigeria. \\ * Correspondent author: maotitoju@gmail.com
}

\begin{abstract}
Research background: The intention of consumers to purchase branded goods and services is a building block for purchasing behaviour in agribusiness especially for fresh leafy vegetables with nutritional and health benefits in Africa. Purpose of the article: To examine the determinants of consumers' intention to purchase fresh leafy vegetables, and to identify the constraints militating against shopping outlet decisions of fresh leafy vegetables by the rural and urban households in the Federal Capital Territory, Nigeria.

Methods: The sampling techniques were employed to collect data from primary source were stratified, purposive and convenience to select 746 respondents (396 of urban and 350 of rural households). But 608 respondents (294 for Urban area and 314 for rural area, which represents $74.2 \%$ and $89.7 \%$, respectively) were later used for the analysis. Convenience sampling was used at a point because there is no reliable sampling frame that was existing for the respective places.

Findings \& Value: This study reveals that are household size, farming as a primary occupation and distance of the consumers' residence to the point of purchase leafy vegetables among both rural and urban households, with the exception of personal income which only influenced the purchasing intention of urban consumers. Poor storage facilities for fresh leafy vegetables was a major constraint to both rural and urban households in the choice of shopping outlets for fresh leafy vegetables in the Federal Capital Territory, Nigeria. All-inclusive policies should be enacted that has the potential to enhance the storage facilities for fresh leafy vegetables. For branded leafy vegetables to be purchased the shopping outlets must be made closer to the residence of the consumers.
\end{abstract}

Key words: fresh leafy vegetables; purchasing intention; rural and urban households JEL Codes: Q12; Q13

\section{INTRODUCTION}

In Nigeria, agriculture is greatly evolving into agribusiness where it is expected that agriculture is practiced as a business and not as a development project. It is on this note that agricultural enterprises and firms have been producing largely for the markets. But the market is now evolving to what it is expected to be globally in term of receiving goods that are of better quality, the marketing and promotional tools to enhance the commercialization of agricultural produce are increasing and taking new dimension. Among these are advertising, packaging, labelling and branding. All these are intended to enhance the farmers' income and possibly the welfare. But the consumers have their own perspective about these promotion tools. Therefore, it is of great importance to investigate the determinants of marketing of agricultural produce and in this context, fresh leafy vegetables, to know this, the factors influencing the intention of branded fresh leafy vegetables are to be examined and the constraints affecting the consumer choice of shopping outlets are very essential in both rural and urban areas. To know the purchasing intention of any good or service is a way to know the marketing strategy to employ by the supplier of such goods or service.

Purchasing intention as defined by Howard (2009) is a state of mental stand that reflects the decision of the consumer to get or buy a good or service in the foreseeable or recent future. Also John and Jagsish (1969) defined consumer purchasing intention as "the attitude of the consumers toward a specific purchasing behaviour and the level of consumer's willingness-to-pay." Consumer purchasing behaviour is primarily rooted in their purchasing intention (Zhang, Zhou and Liu, 2020). Consumer intention to purchase goods or services are determined by socio-economic and other factors. The term purchasing intention in this study means the consumer's decision to buy branded fresh leafy vegetables, that is, consumer's willingness-to-buy fresh leafy vegetables with a brand.

Branding is the process of creating brands in order to differentiate the products of an agribusiness firm those of 
the competitors by creating a unique impression of product or service in the mind of customers. Sammut-Bonnici (2015) defined "brand as a set of tangible and intangible attributes designed to create awareness and identity, and to build the reputation of a product, service, person, place, or organization." American Marketing Association also defined brands as a name, sign, symbol, design or a combination of them that are intended to identify products or services of one seller and to differentiate them from those of another sellers or competitors (PAR Marketing services, n.d).

In this study, the decision of the rural and urban consumers to acquire fresh leafy vegetables that are branded in Nigeria context is to be addressed, essentially the factors influencing such intention. It has been also explained by Ambrose-Oji (2012) that leafy vegetables (LVs) are species of plant originally native to a particular region, or introduced there for quite a long time either through natural process or growers' selection. In SubSahara Africa, nutrient deficiency has been a serious problem for some time now, this nutrition imbalance can be addressed partly by encouraging the consumption of our locally produced plants and livestock rather than depending solely on imported food products. Among the plants that can address this imbalance are leafy vegetables which have vitamins, minerals, anti-oxidants, and some others are cancer defeating ones. The consumption of some of these plants should be done with less processing so that the presence of the vital minerals would not be lost to overheating. Among these plants are leafy vegetables which are more nutritious when consumed fresh with less heat.

From the foregoing, this paper set to investigate the determinants of purchasing intention of branded fresh leafy vegetables, and to investigate the constraints militating against choice of shopping outlets for unbranded fresh leafy vegetables in the Federal Capital Territory, Nigeria.

\section{LITERATURE REVIEW}

Many previous studies have investigated factors that influence market outlets among them are: Alemu, Abrha, and Teklu (2011) worked on the factors that have causeeffect relationship on vegetable channel selection in rural Tugray. Kuma, Baker, Getnet, and Kassa, (2013) used multinomial logit model to examine the determinants of choice of milk marketing outlets in Wolaita zone of Ethiopia. Jari and Fraser (2009) investigated how technical and institutional variables affect marketing choices by smallholder farmers in the Kat River Valley, Eastern Cape Province, South Africa with the application of multinomial logit. In Kenya, Gido, Ayuya, Owuor, and Bokelmann (2013) used multinomial probit analysis to evaluate the characteristics (socio-economic, institutional and product) that influence the choice for African indigenous vegetable (AIV) retail outlets among rural and urban households. Shafiwu, Donkoh and Alhassan (2018) investigated the preferred purchasing outlet of safer vegetables using multinomial logit. In their study Okello, Lagerkvist, Hess, Ngigi, and Karanj (2012) assessed the factors conditioning their choice between open-air markets, roadside markets, supermarkets and specialty markets when buying fresh vegetables by Kale consumers in Kenya using nonparametric analytical method. Using multinomial logit analysis in Kenya, Mutai, Agunda, Muluvi, Kibet, and Maina (2013) investigated the determinants of shift in market participation from village to regional market in Vihiga County. Sharma, Kumar, and Singh (2009) investigated factors that affect choice of market channels by milk producers in India. But they widely embraced supply-oriented approach in evaluating producers' preferences for market retail outlets. But none of these studies looked into the aspect consumer/buyer side of the marketing. The work of Mishra and Gera (2016) revealed that brand awareness and reference group were related directly with consumer purchasing intention. Zhang, Zhou and Liu (2020) used revised theory of reasoned action to test and verify the determinants of consumer purchasing intention and the strategy of marketing employed in energy automobile parts in China and found that social norms had a low subjective influence on the consumers' purchasing intention. Social credit system was identified to purchase intention of the consumers. The study of Frik and Mittone (2019) found that security, awareness, information collection, and control, and company background and consumer reviews had a strong effect on trust and willingness-to-purchase, while website quality plays only a marginal role. Although the perception of trustworthiness and purchasing intention were positively correlated, in some cases participants were more willing to buy from a website that they judged as untrustworthy with regard to privacy.

Jiang and Rosenbloom (2005) examined consumer intention to return online, and found that satisfaction had influence on customer purchase intention at different stages of shopping in e-retailing sector of marketing. The initial shopping experience showed that convenience of shopping and satisfaction had positive relationship with price perception. In Maharashtra-India, Banerji, Birol, Karandikar and Rampal (2016) tested the relationship of branding with purchasing intention of high-iron pearl millet using experimental auctions. And they found out that consumers preferred branding on a global-scale to state ones. Isa, Annuar, Gisip, and Lajuni (2020) investigated and tested impulse purchase orientation, brand orientation, and online purchase as factors affecting Millennials and Generation Z's purchase intention in online shopping.

In their reviewed work, Grunert and Ramus (2005) posited that experience counts in shopping on the internet, this can also hold through for all product. In their work, Bigné-Alcañiz, Ruiz-Mafé, Aldás-Manzano and SanzBlas (2008) posited that the relationship that existed between information dependency and online shopping was positive, so also innovativeness had similar relationship.

Ariffin, Yusof, Putit and Shah (2016) investigated the relationship between the green value, emotional value, environment conscious, consumers' perceived quality, and repurchase intention towards green products at Parkson Bandar Utama, Selangor. 
Approach used in many studies to a large extent has been supply-side based. This is good but the inability to sufficiently consider the demand-side will make the policy advice deduce from such studies to be not all-inclusive because consumers unlike the producers also take vital purchasing decisions. Knowing fully well that decisions of both the producers/suppliers and the consumers/buyers maybe diverse but intended to achieve their respective goals, which are necessary for a successful agribusiness processes.

In this study we focus on the rural and urban consumers of fresh leafy vegetables for these reasons. First, fresh leafy vegetables are produced largely in the rural and peri-urban communities and some urban people as well produce.

Secondly, agribusiness is much more being pushed recently by Government of Nigeria and some international agricultural partners like International Institute of Tropical Agriculture (IITA) and agribusiness would not be completed without taking branding into consideration.

Thirdly, any agriculture and agribusiness intervention would as a matter of fact factor in advertising, packaging and branding as pillars of agribusiness promotion. And such policy planning and design could leverage on studies like this to properly design the programmes for agriculture partners on the factors of great importance and the likely challenges to deal with for easy execution of branding from the angle of rural and urban consumers of fresh leafy vegetables.

The study will contribute to the literature in these manners. First, there have been studies on marketing of fresh leafy vegetables and other crops but none have looked into the consumer intention to purchase fresh leafy vegetables with brands. Based on the foregoing, this paper contributes to agribusiness and marketing literatures with this study on consumer intention to purchase fresh leafy vegetables with brands. Studies like that of Meng, Florkowski, Sarpong, Chinnan, and Resurreccion (2014); Okello et al. (2012) embraced in agricultural marketing and agribusiness used consumer-based empirical approach. However, none of these examined the determinants of consumer intention to buy branded fresh leafy vegetables and at the same time investigated the constraints militating against choice of shopping outlets for unbranded fresh leafy vegetables in the Federal Capital Territory, Nigeria.

\section{DATA AND METHODS}

\section{Data source and sampling procedure}

The sampling techniques employed to collect data from primary source in this study were stratified, purposive and convenience to select the respondents (fresh leafy vegetable consumer households). The Federal Capital Territory was stratified into the rural and urban areas. Two Area Councils were selected from rural area, and two also from urban area. Abuja Municipal and Gwagwalada Area Councils were selected for the Urban area based on certain characteristics, and Kwali and Abaji Area represented the Rural area on the basis of their features. From each Area Council, $50 \%$ of the number of wards that made up the Area Council were selected, which represented five wards from each Area Council in the rural area, making 10 wards for the rural area, and six wards were selected from the urban area, making 12 wards in the urban area. Then, thirty-three and thirty-five households were conveniently selected from each ward selected in the urban and the rural areas respectively, making 396 and 350 households for the Urban and the Rural area, respectively as shown in Table 1. We later used 294 for Urban area and 314 for rural area, which represents $74.2 \%$ and $89.7 \%$, respectively after the data was cleaned to deal with outliers and incomplete questionnaires were dropped. Also, convenience sampling was used at a point because there is no reliable sampling frame that was existing for the respective places.

Table 1: The Matrix of the Selected Sample from the Rural and Urban Areas

\begin{tabular}{|c|c|c|}
\hline Area council & Wards & $\begin{array}{l}\text { Number of } \\
\text { respondents } \\
\text { selected }\end{array}$ \\
\hline \multicolumn{3}{|l|}{ Rural Area } \\
\hline \multirow[t]{5}{*}{ ABAJI } & Rimba Ebaji & 35 \\
\hline & Nuku & 35 \\
\hline & Yaba & 35 \\
\hline & Gurdi & 35 \\
\hline & Gawu & 35 \\
\hline \multirow[t]{5}{*}{ KWALI } & Kilankwa & 35 \\
\hline & Pai & 35 \\
\hline & Wako & 35 \\
\hline & Yeba & 35 \\
\hline & Yangoji & 35 \\
\hline \multicolumn{3}{|l|}{ Urban Area: } \\
\hline \multirow[t]{6}{*}{ ABUJA MUNICPAL } & City Centre & 33 \\
\hline & Garki & 33 \\
\hline & Wuse & 33 \\
\hline & Gwarimpa & 33 \\
\hline & Karu & 33 \\
\hline & Nyanya & 33 \\
\hline \multirow[t]{8}{*}{ GWAGWALADA } & Gwagwalada & 33 \\
\hline & Central & \\
\hline & Kutumku & 33 \\
\hline & Staff & 33 \\
\hline & Quarters & \\
\hline & Paiko & 33 \\
\hline & Zuba & 33 \\
\hline & Anagada & 33 \\
\hline Total for Urban Area & 11 & 396 \\
\hline
\end{tabular}

Source: Computed by the authors.

\section{Empirical Model Specification: Probit Model}

The application of Probit model to achieve the objective on the determinants of consumer intention to purchase branded fresh leafy vegetables was deemed fit because of the qualitative nature of the regressand, that is the dependent variable. The Probit model has been applied for dependent variable that is dichotomous in nature. For this paper, the qualitative variable was dichotomous (discrete) that took 1 if consumer intend to purchase branded fresh leafy vegetables, 0 otherwise. The Probit model was employed to estimate this intention of the consumers. The model is specified as Equation 1-2: 


$$
\pi_{\mathrm{i}}=\Phi\left(\eta_{\mathrm{i}}\right)=\Phi\left(\alpha+\beta_{\mathrm{i}} \mathrm{X}_{\mathrm{i} 1}+\beta_{2} \mathrm{X}_{\mathrm{i} 2}+\cdots+\beta_{\mathrm{k}} \mathrm{X}_{\mathrm{ik}}\right.
$$$$
\pi_{\mathrm{i}}=\Phi\left(\mathrm{X}_{\mathrm{i}}^{\mathrm{t}}\right)
$$

The distribution function for the Standard Normal Random Variable is $\Phi($.$) ; the parameters estimated are \alpha$ and $\beta_{i} ; \pi_{i}$ conditional probability; $\beta_{i}$ coefficients of the independent variables i.e. regressors); $X_{i}$ the explanatory or independent variables, and $\varepsilon_{\mathrm{i}}$ error term. What differentiate the Probit model from Logit model is the normal distribution of errors as stated (Equation 3). Logistic regression model assumes logistic distribution of errors.

$\Phi-1_{\left(\mathrm{Y}_{\mathrm{t}}\right)}=\sum_{\mathrm{k}=\mathrm{o}}^{\mathrm{k}-\mathrm{n}} \beta_{\mathrm{k}} \mathrm{X}_{\mathrm{ik}}^{2} \varepsilon_{\mathrm{i}}$

This is implicitly stated as Equation (4).

$\mathrm{Y}_{\mathrm{t}}^{*}=\beta_{\mathrm{i}} \mathrm{X}+\varepsilon_{\mathrm{i}}$

Where:

$\mathrm{Y}_{\mathrm{i}}^{*}$ the dichotomous dependent variable of the purchasing intention for braded fresh leafy vegetables (if consumer intend to purchase branded fresh leafy vegetables, 0 otherwise); $\mathrm{X}_{\mathrm{i}}$ are the explanatory or independent variables; $\beta_{\mathrm{i}}$ are parameters of the regressors (explanatory or independent variables), and $\varepsilon_{\mathrm{i}}$ error term.

The Equation (4) is explicitly stated as:

$\mathrm{Y}_{\mathrm{i}}^{*}=\alpha+\beta_{1} \mathrm{X}_{1}+\beta_{2} \mathrm{X}_{2}+\beta_{3} \mathrm{X}_{3}+\beta_{4} \mathrm{X}_{4}+\beta_{5} \mathrm{X}_{5}+$ $\beta_{6} X_{6}+\beta_{7} X_{7}+\beta_{8} X_{8}+\varepsilon_{i}$

The independent (explanatory) variables considered as determinants or factors influencing consumer purchasing intention for branded fresh leafy vegetables by the sampled consumers (both rural and urban) in the Probit regression analysis are as shown in Table 2.

Probit regression analysis was conducted for rural consumers and a separate one was conducted for urban consumers of fresh leafy vegetables.

\section{RESULTS AND DISCUSSION}

Consumers' Purchasing Intention for Fresh Leafy Vegetables by Rural and Urban Households in the Study Area

Table 3 shows that majority of the respondents $62.4 \%$ and $57.8 \%$ did not show intention to purchase fresh leafy vegetables among rural and urban households, respectively, while $37.6 \%$ and $42.2 \%$ of the sampled respondents showed intention to buy branded leafy vegetables in the study area. This implies that branded leafy vegetables as sold in super markets and organised shops is yet to be known by majority of the households in the study area.

Factors Influencing Consumers' Intention to Purchase Branded Fresh Leafy Vegetables among Rural and Urban Households in the Federal Capital Territory, Nigeria

The result of the Probit models indicated that household size, and farming as primary occupation influenced consumers' intention to buy branded fresh leafy vegetables for both rural and urban households in the study area. Apart from these two aforementioned variables, distance to the nearest market outlets influenced consumers' intention to buy branded fresh leafy vegetables among the rural households, while age of the household head, and personal income had influence on the urban consumer purchasing intention for fresh leafy vegetables in the study area. As shown in Table 4, the Wald chi-square statistic with the values of $15.12(\mathrm{P}<$ $0.0569)$, and $39.22(\mathrm{P}<0.0000)$ for rural and urban fresh vegetable consumers, respectively were highly significant suggesting the models for the two categories had strong explanatory powers. Table 4 presents the parameter estimates, coefficients, robust standard errors, and the zratios from the Probit models for rural and urban households.

Household Size of the consumers: The result in Table 4 shows that household size of the consumers and the probability to purchase branded leafy vegetables had positive and significant relationship at $10 \%$ and $1 \%$ levels of probability for rural and urban households, respectively in the Federal Capital Territory. This implies that intention to buy branded fresh leafy vegetables increases with consumer household size in both the rural and urban category. Looking at Table 4 critically showed that large household size is an important factor for intention to purchase branded fresh leafy vegetables irrespective of the setting either rural or urban in Federal Capital Territory, Nigeria. This contradicts the finding of Slamet, Nakayasu, and Bai (2016) that posited a negative relationship between household size and purchasing.

Farming as primary occupation of the household head: The results in Table 4 showed that farming as primary occupation of the fresh leafy consumers and the probability of the consumers' intention to buy fresh leafy vegetables had negative significant relationship at 5\% and $1 \%$ levels of probability among rural and the urban households in the study area. This is in agreement with the theoretical expectation. This implies that consumers that were farmers did not intend to buy branded fresh leafy vegetables probably because they produced fresh leafy vegetables. Farming as a primary occupation has great influence on consumer purchasing behaviour.

Distance to the nearest market outlets: Distance of the consumer's residence to the nearest market outlet of fresh leafy vegetables in the rural area had an inverse significant relationship with consumers' intention to purchase branded fresh leafy vegetables at $10 \%$ level of significance (Table 4). This finding agreed with the findings of Otitoju (2013). Proximity counts in consumer purchasing behaviour, which means the farther the market outlets to the consumers the more they did not intend to purchase branded fresh leafy vegetables by rural consumer households.

Age of the consumer: Age of the consumer and the probability of the consumer intention to purchase branded fresh leafy vegetables had significantly positive relationship among the urban households at $99 \%$ level of precision. 
Table 2: Description, Measurement and Expected Signs of the Dependent and the Independent Variables (Regressors) in the Probit Regression Analysis

\begin{tabular}{|c|c|c|c|c|c|}
\hline Variable Names & Variable Description and Measurement & Unit of Measurement & Parameters & $\begin{array}{l}\text { Variable } \\
\text { Notations }\end{array}$ & $\begin{array}{l}\text { Expected sign (a priori } \\
\text { expectation) }\end{array}$ \\
\hline $\begin{array}{l}\text { Consumer intention to } \\
\text { buy/purchase branded fresh } \\
\text { leafy vegetables }\end{array}$ & $\begin{array}{l}\text { Binary dependent variable, measured as } \\
\text { a dummy, } 1 \text { if consumer intend to } \\
\text { purchase, } 0 \text { otherwise. }\end{array}$ & Dummy & - & $\mathrm{Y}_{\mathrm{i}}^{*}$ & \\
\hline Age of the consumer & $\begin{array}{l}\text { The number of years the consumer has } \\
\text { been living }\end{array}$ & Years & $\beta_{1}$ & $\mathrm{X}_{1}$ & \pm \\
\hline Sex of the consumer & The sex category of the consumer & $\begin{array}{l}\text { Dummy (measured as } 1 \text { for male, } 0 \\
\text { otherwise) }\end{array}$ & $\beta_{2}$ & $\mathrm{X}_{2}$ & \pm \\
\hline $\begin{array}{l}\text { Educational Level of the } \\
\text { consumer }\end{array}$ & $\begin{array}{l}\text { The number of years spent in formal } \\
\text { schooling }\end{array}$ & Number of years & $\beta_{3}$ & $\mathrm{X}_{3}$ & + \\
\hline Household size & $\begin{array}{l}\text { Number of persons in the consumer's } \\
\text { household }\end{array}$ & Number of persons & $\beta_{4}$ & $\mathrm{X}_{4}$ & + \\
\hline $\begin{array}{l}\text { Personal income of the } \\
\text { consumer }\end{array}$ & $\begin{array}{l}\text { This is the amount of money earned } \\
\text { within a month }\end{array}$ & Amount in naira & $\beta_{5}$ & $\mathrm{X}_{5}$ & + \\
\hline Occupation of the consumer & The primary occupation of the consumer & $\begin{array}{l}\text { Dummy (measured as } 1 \text { if farming } \\
\text { is the primary occupation, } 0 \\
\text { otherwise) }\end{array}$ & $\beta_{6}$ & $\mathrm{X}_{6}$ & - \\
\hline $\begin{array}{l}\text { Fresh leafy vegetable } \\
\text { expenditure }\end{array}$ & $\begin{array}{l}\text { The amount of money expended on } \\
\text { fresh leafy vegetables in a month }\end{array}$ & The amount of money in naira & $\beta_{7}$ & $\mathrm{X}_{7}$ & - \\
\hline $\begin{array}{l}\text { Distance to the point of } \\
\text { purchase in kilometres }\end{array}$ & $\begin{array}{l}\text { The distance in kilometres from the } \\
\text { consumer residence to the point of } \\
\text { purchase }\end{array}$ & Distance in kilometres & $\beta_{8}$ & $\mathrm{X}_{8}$ & $?$ \\
\hline
\end{tabular}

Table 3: Frequency Distribution of consumers' intention to buy branded fresh leafy Vegetables among rural and urban households

Consumers' intention to purchase Rural Households Urban Households

branded fresh leafy vegetables Frequency Percentage Frequency Percentage

\begin{tabular}{lrrrr}
\hline No & 196 & 62.4 & 170 & 57.8 \\
Yes & 118 & 37.6 & 124 & 42.2 \\
Total & 314 & 100.0 & 294 & 100.0 \\
\hline
\end{tabular}

Source: Computed from field data, 2019. 
Table 4: Parameter Estimates of the Factors Influencing Consumers' Intention to Buy Branded Fresh Leafy Vegetables among Urban and Rural Households in Federal Capital Territory, Nigeria

Explanatory Variables Parameters Urban Households Rural Households

Age of the consumer (years) Coefficient Robust Standard Error z-value Coefficient Robust Standard Error z-value

Sex of the consumer (Dummy, 1 if male, 0 otherwise)

$\beta_{1}$
0.02184

Educational Level of the consumer (years spent in formal schooling) $\beta_{3}$

0.18187

$-0.00118$

0.07249

Household size (number of persons in the consumer household)

$4.10 \mathrm{e}-06$

Personal income of the consumer (Monthly income in naira)

$4.10 \mathrm{e}-06$

$-0.00001$

occupation)

Fresh leafy vegetable expenditure (Amount of money expended on

consumption of fresh leafy vegetables per month)

Distance of the consumer residence to the nearest fresh leafy $\quad \beta_{8}$

\subsection{6}

$-0.02527$

vegetables market outlet

Constant

$-1.3993$ 0.00862 .51

$-0.00837$

$0.0107 \quad-0.78$

Number of observation $=294$

Log-Likelihood $\mathrm{Chi}^{2} 2(8)=-182.867$

Wald $\mathrm{Chi}^{2}(8)=39.22$

Prob $>$ chi $^{2}=0.0000$

Pseudo $\mathrm{R}^{2}=0.0865$

Note: *,**,*** $10 \%, 5 \%, 1 \%$ levels of significance.

$\begin{array}{lllll}0.1558 & 1.17 & 0.05113 & 0.1654 & 0.31\end{array}$

Source: Computed from field data, 2019. 
Table 5: Frequency Distribution and Mean of Constraints militating against consumers' choice of shopping outlets of fresh leafy vegetables by rural and urban households in the Federal Capital Territory, Nigeria

\begin{tabular}{|c|c|c|c|c|c|c|c|}
\hline Constraints & Area & Very Serious & Serious & Not Serious & Not Very Serious & Mean & $\begin{array}{l}\text { Standard } \\
\text { Deviation }\end{array}$ \\
\hline \multirow[t]{2}{*}{ Lack of availability of fresh leafy vegetables in the Market outlets } & Rural & $26(8.8)$ & $78(26.5)$ & $102(34.7)$ & $88(29.9)$ & 2.14 & 0.949 \\
\hline & Urban & $30(9.6)$ & $92(29.3)$ & $154(49.0)$ & $38(12.1)$ & 2.36 & 0.816 \\
\hline \multirow[t]{2}{*}{ Poor storage facilities for fresh leafy vegetables } & Rural & $102(34.7)$ & $110(37.4)$ & $59(20.1)$ & $23(7.8)$ & $2.98 * *$ & 0.929 \\
\hline & Urban & $148(47.1)$ & $86(27.4)$ & $66(21.0)$ & $14(4.2)$ & $3.17 * *$ & 0.912 \\
\hline \multirow[t]{2}{*}{ Lack of time to go to the known markets outlets of fresh leafy vegetables } & Rural & $28(9.5)$ & $68(23.1)$ & $124(42.2)$ & $74(25.2)$ & 2.17 & 0.915 \\
\hline & Urban & $36(11.5)$ & $89(28.3)$ & $140(44.6)$ & $49(15.6)$ & 2.36 & 0.899 \\
\hline \multirow[t]{2}{*}{ Far distance to go to the markets outlets of fresh leafy vegetables } & Rural & $48(16.3)$ & $74(25.2)$ & $114(38.8)$ & $58(19.7)$ & 2.38 & 0.979 \\
\hline & Urban & $42(13.4)$ & $80(25.5)$ & $144(45.9)$ & $48(15.3)$ & 2.37 & 1.046 \\
\hline \multirow[t]{2}{*}{ Lack of access road to the markets outlets of fresh leafy vegetables } & Rural & $70(23.8)$ & $62(21.1)$ & $92(31.3)$ & $70(23.8)$ & 2.44 & 1.097 \\
\hline & Urban & $79(25.2)$ & $68(21.7)$ & $113(36.0)$ & $54(17.2)$ & 2.25 & 1.04 \\
\hline \multirow[t]{2}{*}{ High cost of fresh leafy vegetables in the market outlets } & Rural & $62(21.1)$ & $70(23.8)$ & $132(44.9)$ & $30(10.2)$ & $2.55 * *$ & 0.936 \\
\hline & Urban & $46(14.6)$ & $70(22.3)$ & $118(37.6)$ & $80(25.5)$ & 2.26 & 0.999 \\
\hline \multirow[t]{2}{*}{ Inadequate information about fresh leafy vegetables } & Rural & $72(24.5)$ & $58(19.7)$ & $102(34.7)$ & $62(21.1)$ & 2.47 & 1.079 \\
\hline & Urban & $58(18.5)$ & $98(31.2)$ & $96(30.6)$ & $26(19.7)$ & $2.50 * *$ & 1.008 \\
\hline \multirow[t]{2}{*}{ The quality of the fresh leafy vegetables is not always guaranteed } & Rural & $48(16.3)$ & $78(26.5)$ & $105(35.7)$ & $63(21.4)$ & 2.37 & 0.999 \\
\hline & Urban & $66(21.0)$ & $102(32.5)$ & $101(32.5)$ & $45(14.3)$ & $2.60 * *$ & 0.974 \\
\hline
\end{tabular}

Source: Computed from field data 2019 
This tallied with the a priori expectation. This agrees with the work of Jenefa, Kumar, and Kadyan (2013) that age of the consumer has direct relationship with the buying behaviour. Roitner-Schobesberger, Darnhofer, Somsook, and Vogl (2008) also posited that older consumer tend to have higher purchasing intention. This implies that the older consumers showed greater purchasing intention for branded fresh leafy vegetables than their younger counterparts. One of the plausible explanations here is that the younger household heads were not so much interested in branded fresh leafy vegetables in the urban areas of Federal Capital Territory, Nigeria.

Personal income: Personal income has the propensity for purchasing intention. The result in Table 4 showed that personal monthly income had positive relationship with the purchasing intention for branded fresh leafy vegetables in the Federal Capital Territory at 5\% level of significance. The higher the personal income of the consumers the more the tendency the intention to purchase branded fresh leafy vegetables by the urban households. This agrees with the work of Jenefa, Kumar, and Kadyan (2013) that monthly income has direct relationship with the buying behaviour. Wekeza and Sibdana (2019) also established a positive relationship between income and purchasing intention. Slamet, Nakayasu, and Bai (2016) posited that income and organic vegetable purchasing were positively related. This result agrees with the work of RoitnerSchobesberger, Darnhofer, Somsook, and Vogl (2008), and Gracia and de Magistris (2008) that found high levels of income positively influenced purchasing intention.

Constraints militating against choice of Consumers' Shopping Outlets for Fresh Leafy Vegetables among the Rural and Urban Households

From Table 5, the major constrains militating against the choice of shopping outlets for fresh leafy vegetables were poor storage facilities for fresh leafy vegetables both at rural and urban households with mean scores of 2.98 and 3.17, respectively. This agrees with the findings of Aminu (2013) that infrastructure challenge is one of the major constraints militating against online shopping. Also, inadequate information about fresh leafy vegetables, and the quality of the fresh leafy vegetables is not always guaranteed were also identified as major constraints militating choice of shopping outlets with mean scores of 2.50 and 2.60, respectively among the urban households. Furthermore, high cost of fresh leafy vegetables in the market outlets with mean score of 2.55 was also identified as a major constraint facing urban households in the choice of fresh leafy vegetables shopping outlets as shown in Table 5.

\section{CONCLUSION AND RECOMMENDATIONS}

The determinants of consumer purchasing intention of branded fresh leafy vegetables are household size, farming as a primary occupation and distance of the consumers' residence to the point of purchase leafy vegetables among both rural and urban households, with the exception of personal income which only influenced the purchasing intention of urban consumers. Poor storage facilities for fresh leafy vegetables was a major constraint to both rural and urban households in the choice of shopping outlets for fresh leafy vegetables in the Federal Capital Territory, Nigeria. All-inclusive policies should be enacted that has the potential to enhance the storage facilities for fresh leafy vegetables. For branded leafy vegetables to be purchased the shopping outlets must be made closer to the residence of the consumers.

\section{REFERENCES}

ALEMU, A. E., ABRHA, B. K., \& TELlU, G. U. Y. (2011) Determinants of vegetable channel selection in rural Tagray, Northern Ethopia. International Journal of Research in Commerce and Management, 2, 15 - 20

AMBROSE-OJI, B. (2012). Urban food systems and african indigenous vegetables: defining the spaces and places for African indigenous vegetables in urban and peri-urban agriculture. In African Indigenous Vegetables in Urban Agriculture, (eds) M.Shackleton, M. W. Pasquini, and A. W. Drescher, 134. London: Earthscan.

AMINU, S. A. (2013). Challenges militating against adoption of online shopping in retail industry in Nigeria. Journal of Marketing Management, 1(1), 2333.

ARIFFIN, S., YUSOF, J. M, PUTIT, L., \& SHAH, M. I. A. (2016). Factors influencing perceived quality and repurchase intention towards green products. Procedia Economics and Finance, 37, 391-396. DOI: https://doi.org/10.1016/S2212-5671(16)30142-3

BIGNÉ-ALCAÑIZ, E., RUIZ-MAFÉ, C., ALDÁSMANZANO, J., \& SANZ-BLAS, S. (2008). Influence of online shopping information dependency and innovativeness on internet shopping adoption. Online Information Review, 32(5), 648-667. DOI: https://doi.org/10.1108/14684520810914025

FRIK, A., \& MITTONE, L. (2019). Factors influencing the perception of website privacy trustworthiness and users' purchasing intentions: the behavioral economics perspective, Journal of theoretical and applied electronic commerce research, 14(3), 89-125, DOI: https://doi.org/10.4067/S0718-18762019000300107

GIDO, E. O., AYUYA, O. I., OWUOR, G., \& BOKELMANN, W. (2016). Consumer's choice of retail outlets for African indigenous vegetables: Empirical evidence among rural and urban households in Kenya, Cogent Food \& Agriculture, 2(1), 1248523, DOI: https://doi.org/10.1080/23311932.2016.1248523

GRACIA, A., \& DE MAGISTRIS, T. (2008). The demand for organic foods in the South of Italy: A discrete choice model. Food Policy, 33, 386-396. DOI: https://doi.org/10.1016/j.foodpol.2007.12.002

GRUNERT, K. G., \& RAMUS, K. (2005). Consumers' willingness to buy food through the internet. British Food Journal, 107(6), 381-403. DOI: https://doi.org/10.1108/00070700510602174

HOWARD, J. (1989). Consumer Behavior in Marketing Strategy, Prentice-Hall, New York, NY.

ISA, N. F., ANNUAR, S. N. S., GISIP, I. A. \& LAJUNI, N. (2020). Factors influencing online purchase 
intention of millennials and gen $\mathrm{z}$ consumers, Journal of Applied Structural Equation Modelling, 4(2), 21-43. DOI:10.47263/JASEM.4(2)03

KUMA, B., BAKER, D., GETNET, K., \& KASSA, B. (2013). Factors affecting milk market outlet choices in Wolaita zone, Ethiopia. African Journal of Agricultural Research, 8(21), 2493-2501. https://academicjournals.org/journal/AJAR/articlefull-text-pdf/A613D2234360

JARI, B., \& FRASER, G. C. G. (2009). An analysis of institutional and technical factors influencing agricultural marketing amongst smallholder farmers in the Kat River Valley. Eastern Cape Province, South Africa. African Journal of Agricultural Research, 4 (11), $1129 \quad$ - 1137. https://academicjournals.org/journal/AJAR/articlefull-text-pdf/D9C79BF37467

JENEFA, L. KUMAR, R. M., \& KADYAN, J. S. (2013). Socio-economic factors influencing the buying behaviour with special reference to selected garment retail outlet in Chennai. International Journal of Business and Management Invention, 2(12), 1 -11.

JIANG, P., \& ROSENBLOOM, B. (2005). Customer intention to return online: price perception, attributelevel performance, and satisfaction unfolding over time. European Journal of Marketing, 39(1/2), 150174. doi: https://doi.org/10.1108/03090560510572061

JOHN, A. H., \& JAGSISH, N. S. (1969) Theory of Buyer Behavior (Marketing), John Wiley \& Sons, New York, NY, USA.

MENG, T., FLORKOWSKI, W. J., SARPONG, D. B., CHINNAN, M.S., \& RESURRECCION, A.V.A. (2014). Consumer's food shopping choice in Ghana: Supermarket or traditional outlets? International Food and Agribusiness Management Review, 17, 107-129. DOI: $10.22004 /$ ag.econ. 164600

MISHRA, N. K., \& GERA, N. (2016). Determinants of consumer buying behaviour of private label brands in delhi in retail: proposition and test of SEM Model. International Research Journal of Management Sociology \& Humanity, 7(3), 56 - 69 .

MUTAI, B. K., AGUNDA, E. N., MULUVI, A. S., KIBET, L. K., \& MAINA, M. C. (2013). Determinants of smallholder sweet potato farmers' participation in different market options: The Case of Vihiga County, Kenya, Journal of Development and Agricultural Economics, 5(8), 314-320. DOI: http://doi.org/10.5897/JDAE12.138

OKELLO, J. J., LAGERKVIST, C., HESS, S., NGIGI, M., \& KARANJA, N. (2012). Choice of fresh vegetable retail outlets by developing-country urban consumers: the case of Kale consumers in Nairobi, Kenya. European Journal of Development Research, 24, 434-449.

DOI: https://doi.org/10.1057/ejdr.2011.58

OTITOJU, M. A. (2013). The effects of climate change adaptation strategies on food crop production efficiency in southwestern Nigeria. $\mathrm{PhD}$ thesis, Department of Agricultural Economics, University of Nigeria, Nsukka, Nigeria.
PAR MARKETING SERVICES (N.D). Barding. http://parmarketingservices.com/Docs/Branding $\% 20$ White\%20Paper.pdf.

ROITNER-SCHOBESBERGER, B., DARNHOFER, I., SOMSOOK, S., \& VOGL, C. R. (2008). Consumer perceptions of organic foods in Bangkok, Thailand. Food Policy, 33(2), 112-121. DOI: https://doi.org/10.1016/j.foodpol.2007.09.004

SAMMUT-BONNICI, T. (2015). Brand and branding. In: Wiley Encyclopaedia of Management. Vol. 12. Strategic Management. John Wiley \& Sons, Ltd. DOI: $10.1002 / 9781118785317$. weom120161

SHAFIWU, A. B., DONKOH. S. A., \& ALHASSAN, H, (2018). Consumers' preferred purchasing outlet of safer vegetables in Ouagadougou, Burkina Faso, Cogent Food \& Agriculture, 4:1, 1492360, DOI: https://doi.org/10.1080/23311932.2018.1489714

SHARMA, V. P., KUMAR, K., \& SINGH, R. V. (2009). Determinant of small-scale farmer inclusion in emerging modern agri-food markets: A study of the dairy industry in India (W.P. No. 2009-02-01). India Institute of Management, Ahmedabad.

SLAMET, A. L., NAKAYASU, A., \& BAI, H. (2016). The determinants of organic vegetable purchasing in Jabodetabek Region, Indonesia. Foods, 5(4), 85, 1-18. DOI: $\underline{\text { https://doi.org/10.3390/foods5040085 }}$

WEKEZA, S. V., \& SIBDANA, M. (2019). Factors influencing consumer purchase intentions of organically grown products in Shelly Centre, Port Shepstone, South Africa. International Journal of Environmental Research and Public Health, 16, (956), 1-26. DOI: http://doi.org/10.3390/ijerph16060956

ZHANG, S., ZHOU, C., \& LIU, Y. (2020). Consumer purchasing intentions and marketing segmentation of remanufactured new-energy auto parts in China. Mathematical Problems in Engineering, 5647383, 18. DOI: https://doi.org/10.1155/2020/5647383 